\title{
HUBUNGAN ANTARA FREKUENSI KEMOTERAPI DAN STATUS NUTRISI PASIEN KANKER YANG MENJALANI KEMOTERAPI DI RUANG SANJIWANI RSUP SANGLAH DENPASAR
}

\author{
Ni Made Ayu Puspa Dewi ${ }^{1}$, Putu Oka Yuli Nurhesti ${ }^{2}$, Made Rini Damayanti ${ }^{3}$ \\ ${ }^{1}$ Mahasiswa Program Studi Sarjana Keperawatan Fakultas Kedokteran Universitas Udayana \\ ${ }^{2,3}$ Staff Dosen Program Studi Sarjana Keperawatan Fakultas Kedokteran Universitas Udayana \\ Alamat Korespondensi: untukpuspa@gmail.com
}

\begin{abstract}
Abstrak
Kemoterapi adalah salah satu terapi yang efektif dalam penatalaksanaan kanker. Kemoterapi yang dilakukan secara berulang dapat menyebabkan berbagai efek samping. Perubahan status nutrisi merupakan salah satu efek samping kemoterapi. Tujuan penelitian ini yaitu untuk mengetahui hubungan antara frekuensi kemoterapi dan status nutrisi pasien kanker yang menjalani kemoterapi di Ruang Sanjiwani RSUP Sanglah Denpasar. Penelitian ini merupakan penelitian retrospektif yang menggunakan rekam medis pada sistem informasi rumah sakit sebagai sumber data penelitian. Teknik sampling yang digunakan ialah purposive sampling dengan menetapkan 80 pasien kanker yang menjalani kemoterapi pada bulan Maret tahun 2018 sebagai sampel. Frekuensi kemoterapi pada sebagian besar responden termasuk dalam kategori rendah (kemoterapi sebanyak 1-3 seri) (65\%) dan status nutrisi sebagian besar dalam kategori ideal (IMT 18,5 - 25,0 kg/m²) (73,8\%). Hasil uji korelasi Spearman Rank menemukan bahwa ada hubungan yang signifikan antara frekuensi kemoterapi dan status nutrisi pasien kanker yang menjalani kemoterapi di Ruang Sanjiwani RSUP Sanglah Denpasar ( $p$ value $=0,00 ; \alpha=0,05 ; r=-0,79$ ). Koefisien determinan (R) pada uji korelasi tersebut didapat sebesar 62,4\% yang artinya sebagian besar faktor frekuensi kemoterapi dapat mempengaruhi perubahan status nutrisi pasien. Kesimpulan penelitian yaitu ada hubungan negatif kuat yang bermakna antara frekuensi kemoterapi dan status nutrisi pasien kanker yang dinyatakan dengan semakin banyak frekuensi kemoterapi maka semakin rendah status nutrisi yang dimiliki pasien begitu pula sebaliknya.
\end{abstract}

Kata Kunci: Frekuensi Kemoterapi, Pasien Kanker, Status Nutrisi

\begin{abstract}
Chemotherapy is one of the most effective therapy for cancer management. Repeated chemotherapy may cause various side effects. It can affect the nutrition status of a cancer patient. This study aimed to determine the relationship between chemotherapy's frequency and nutrition status on cancer patients who underwent chemotherapy in Sanjiwani Room at Sanglah General Hospital, Denpasar. This is a retrospective study based on hospital information systems' medical records. This study a purposive sampling technique and 80 patients were chosen as a sample. This study found that most cancer patients had a low category of chemotherapy's frequency (1-3 cycles of chemotherapy) (65\%) and most of them had ideal nutrition status (BMI 18,5 - 25,0 kg/m2) (73,8\%). Spearman Rank correlation test showed that there was a significant relationship between chemotherapy's frequency and nutrition status on cancer patients who underwent chemotherapy in Sanjiwani Room at Sanglah General Hospital, Denpasar (pvalue $=0.00 ; \alpha=0,05 ; \mathrm{r}=-0.79)$. The determinant's coefficient $(\mathrm{R})$ of this study is known as $62,4 \%$ which means most chemotherapy frequency factors may affect the patient's nutrition status. In conclusion, there a strong negative correlation between chemotherapy's frequency and cancer patient's nutrition status. The more chemotherapy's frequency makes nutrition status on cancer patients who underwent chemotherapy is less than ideal and vice versa.
\end{abstract}

Keywords: Cancer Patient, Chemotherapy's Frequency, Nutrition Status 


\section{PENDAHULUAN}

Kanker adalah penyakit yang ditimbulkan oleh pertumbuhan progresif dari sel abnormal yang menjadikan tubuh kehilangan kendali dalam mempertahankan kondisi fisiologisnya (Brunner \& Suddarth, 2013; Rif'atunnia, 2017). World Health Organization (2018) menyatakan bahwa kanker menjadi penyebab mortalitas kedua di dunia dengan 9,6 juta data kasus. Prevalensi kanker di Indonesia diperkirakan sekitar 347.000 jiwa (Riskesdas, 2017). Berdasarkan Riskesdas (2018) kanker merupakan pembunuh nomor dua di Bali.

$$
\text { Penatalaksanaan kanker }
$$

biasanya dilakukan dengan berbagai macam terapi (Citra, 2012). Kemoterapi adalah salah satu yang paling sering diaplikasikan (Susanti, 2016). Pengobatan dengan kemoterapi dilakukan secara berseri dan kontinyu (Unit Promosi Kesehatan RSUP Dr. Sardjito, 2015).

Jumlah kemoterapi biasanya terdiri dari enam sampai delapan seri tergantung pada kondisi pasien (Priestman, 2012). Frekuensi kemoterapi dapat berbeda-beda menyesuaikan dengan stadium kanker, tujuan terapi, jenis obat sitotoksik yang digunakan dan respon tubuh pasien (Unit Promosi Kesehatan RSUP Dr. Sardjito, 2015). Kemoterapi pada sebagian besar pasien kanker dapat berjumlah lebih dari lima seri (Astika, 2017).

Kemoterapi berseri tidak hanya menghancurkan sel kanker, namun juga sel tubuh normal (Hidayattulah, 2015). Sutandyo (2010) menyatakan proses absorbs nutrisi pada saluran cerna dapat terhambat oleh karena kemoterapi. Hal tersebut merupakan salah satu efek samping yang dapat timbul pada pasien kanker yang mendapat kemoterapi. Timbulnya efek samping dapat mengganggu aspek nutrisi pada pasien kanker.

Nutrisi merupakan proses yang mencakup pemasukkan makanan atau minuman hingga pendistribusiannya ke seluruh tubuh (Sutandyo, 2010). Nutrisi yang baik dapat membantu meningkatkan imunitas, mempercepat perbaikan sel, membentuk jaringan tubuh, dan memperkecil risiko infeksi (Khairina, 2009). Baik buruknya kondisi nutrisi dapat diukur melalui status nutrisi (Departemen Kesehatan RI, 2011).

Status nutrisi merupakan suatu penilaian yang menggambarkan keseimbangan asupan nutrisi dengan kebutuhan nutrisi yang diperlukan oleh tubuh (Khairina, 2009). Status nutrisi pada pasien kanker dapat dipengaruhi oleh faktor internal (usia, aktivitas fisik, infeksi, jenis kanker, efek samping terapi) dan faktor eksternal (pengetahuan, perkerjaan, pendapatan, dan budaya) (Departemen Kesehatan RI, 2011; Ang, Thomas, \& Young, 2012). Status nutrisi dapat dihitung dengan metode antopometri seperti indeks massa tubuh (IMT) (Departemen Kesehatan RI, 2011). IMT membagi status nutrisi menjadi tiga kategori seperti kurang, lebih dan ideal. Status nutrisi ideal penting bagi kualitas hidup pasien kanker (Hariani, 2009).

Ruang Sanjiwani Rumah Sakit Umum Pusat (RSUP) Sanglah Denpasar merupakan ruang kemoterapi untuk pasien kanker rawat jalan. Belum ada penelitian yang pernah dilakukan di ruangan tersebut. Hasil studi pendahuluan yang dilakukan peneliti mendapatkan bahwa tujuh dari sepuluh pasien yang menjalani kemoterapi merasa mengalami penurunan berat badan dan berasumsi jika pengobatan dalam banyak seri ialah penyebabnya. Berdasarkan hal tersebut maka peneliti tertarik untuk melakukan validasi 
melalui penelitian mengenai hubungan antara frekuensi kemoterapi dan status nutrisi pasien kanker di lokasi tersebut.

\section{METODE PENELITIAN}

Penelitian ini merupakan jenis penelitian retrospektif yang memungkinkan peneliti untuk mengamati peristiwa yang telah terjadi melalui sumber data sekunder seperti sistem informasi rekam medis.

Seluruh pasien kanker yang menjalani kemoterapi di Ruang Sanjiwani RSUP Sanglah Denpasar selama tahun 2018 merupakan populasi penelitian. Rata-rata pasien per bulan pada tahun tersebut diketahui sebanyak 73 pasien. Teknik purposive sampling dan kriteria inklusi berupa pasien yang terdaftar menjalani kemoterapi pada bulan Maret tahun 2018 di rekam medis ruangan tersebut digunakan untuk mendapatkan sampel. Sampel penelitian berjumlah 80 responden.

Pengumpulan data dilakukan di instalasi rekam medis RSUP Sanglah
Denpasar pada tanggal 27 hingga 28 Mei 2019.

Lembar observasi digunakan untuk mengumpulkan data demografi, frekuensi kemoterapi dan status nutrisi (IMT) responden.

Peneliti telah memperoleh ethical clearance dari Komisi Etik Penelitian FK Unud/RSUP Sanglah dan memperoleh ijin dari direktur rumah sakit untuk melakukan penelitian. Sistem Informasi Rekam Medis Rumah Sakit Sanglah (SIMARS) di komputer milik instalasi rekam medis digunakan untuk mendapatkan data. Akses SIMARS diperoleh dari peminjaman username dan password milik petugas rekam medis.

Analisis data yang digunakan ialah analisis univariat untuk menampilkan karakteristik responden dan analisis bivariat menggunakan uji korelasi Spearman Rank dipilih karena data variabel tidak terdistribusi normal.

\section{HASIL PENELITIAN}

Tabel 1. Karakteristik Responden Penelitian

\begin{tabular}{lcc}
\hline \multicolumn{1}{c}{ Data Demografi } & (n) & Persentase \\
\hline Jenis Kelamin & 32 & $40 \%$ \\
\hline Laki-Laki & 48 & $60 \%$ \\
\hline Perempuan & & \\
\hline Usia & 27 & $33,8 \%$ \\
\hline Dewasa Muda (18-40 tahun) & 51 & $63,7 \%$ \\
\hline Dewasa Madya (41-60 tahun) & 2 & $2,5 \%$ \\
\hline Dewasa Akhir (>60 tahun) & & $13,8 \%$ \\
\hline Pendidikan Terakhir & 11 & $42,5 \%$ \\
\hline Tidak Sekolah & 34 & $7,5 \%$ \\
\hline SD & 6 & $28,7 \%$ \\
\hline SMP & 23 & $7,5 \%$ \\
\hline SMA & 6 & $23,6 \%$ \\
\hline Perguruan Tinggi & & $16,3 \%$ \\
\hline Jenis Pekerjaan & 19 & $1,3 \%$ \\
\hline Karyawan Swasta & 13 & $21,2 \%$ \\
\hline Wirausaha & 1 & $27,4 \%$ \\
\hline Guru & 17 & $3,8 \%$ \\
\hline Petani & 22 & $1,3 \%$ \\
\hline Buruh & 3 & $3,8 \%$ \\
\hline PNS & 1 & $1,3 \%$ \\
\hline Mahasiswa & 3 & \\
\hline Tidak Bekerja & 1 & \\
\hline Pensiunan & & \\
\hline
\end{tabular}


Tabel 1 menunjukkan bahwa sebagian besar responden merupakan perempuan $(60 \%)$. Usia responden mayoritas termasuk kelompok usia dewasa madya $(63,7 \%)$. Tingkat pendidikan terakhir yang dimiliki hampir sebagian besar responden merupakan SD $(42,5 \%)$ dan responden penelitian terbanyak diketahui bekerja sebagai buruh $(27,4 \%)$.

Tabel 2. Distribusi Frekuensi Responden berdasarkan Jenis Kanker

\begin{tabular}{lcc}
\hline \multicolumn{1}{c}{ Jenis Kanker yang Diderita } & (n) & Persentase \\
\hline Kanker Nasofaring & 28 & $35 \%$ \\
\hline Kanker Serviks & 3 & $3,8 \%$ \\
\hline Melanoma Malignan & 1 & $1,3 \%$ \\
\hline Kanker Paru & 8 & $10 \%$ \\
\hline Kanker Lidah & 6 & $7,3 \%$ \\
\hline Kanker Ovarium & 1 & $1,3 \%$ \\
\hline Kanker Payudara & 12 & $15 \%$ \\
\hline Kanker Kolorektal & 3 & $3,8 \%$ \\
\hline Kanker Endometrium & 2 & $2,5 \%$ \\
\hline Kanker Vulva & 1 & $1,3 \%$ \\
\hline Kanker Buli & 1 & $1,3 \%$ \\
\hline Kanker Mandibula & 2 & $2,5 \%$ \\
\hline Kanker Prostate & 5 & $6,1 \%$ \\
\hline Leukemia & 1 & $1,3 \%$ \\
\hline Kanker Pankreas & 6 & $7,5 \%$ \\
\hline \multicolumn{1}{c}{ JUMLAH } & 80 & $100 \%$ \\
\hline
\end{tabular}
$(35 \%)$.

Tabel 2 menunjukkan bahwa responden terbanyak menderita kanker nasofaring

Tabel 3. Distribusi Frekuensi Responden berdasarkan Stadium Kanker

\begin{tabular}{ccc}
\hline Stadium Kanker & (n) & Persentase \\
\hline II & 23 & $28,7 \%$ \\
\hline III & 43 & $53,8 \%$ \\
\hline IV & 14 & $17,5 \%$ \\
\hline JUMLAH & 80 & $100 \%$ \\
\hline
\end{tabular}

Tabel 3 menunjukkan bahwa sebagian besar responden mengalami kanker dengan stadium III $(53,8 \%)$.

Tabel 4. Distribusi Frekuensi Responden berdasarkan Jenis Kemoterapi

\begin{tabular}{lcc}
\hline \multicolumn{1}{c}{ Jenis Kemoterapi } & (n) & Persentase \\
\hline Primer (Cisplatin) & 6 & $7,5 \%$ \\
\hline Primer (Carboplatin) & 1 & $1,3 \%$ \\
\hline Kombinasi (Bleomisin-Oncovin-Mitomisin) & 35 & $43,8 \%$ \\
\hline Kombinasi (Paxus-Carboplatin) & 21 & $26,3 \%$ \\
\hline Kombinasi (Paxus-Cisplatin) & 4 & $13 \%$ \\
\hline $\begin{array}{l}\text { Adjuvan (Kombinasi Paxus-Carboplatin }+ \\
\text { Radioterapi Cobalt 60) }\end{array}$ & 1 & $1,3 \%$ \\
\hline $\begin{array}{l}\text { Adjuvan (Kombinasi Bleomisin-Oncovin- } \\
\text { Mitomisin + Radioterapi Cobalt 60) }\end{array}$ & 1 & $1,3 \%$ \\
\hline $\begin{array}{l}\text { Adjuvan (Kombinasi Bleomisin-Oncovin- } \\
\text { Mitomisin + Post-Masektomi) }\end{array}$ & 80 & $100 \%$ \\
\hline JUMLAH & mendapat terapi kombinasi Bleomisin- \\
\hline Tabel 4 menunjukkan bahwa & Oncovin-Mitomisin (43,8 \%).
\end{tabular}


Tabel 5. Gambaran Umum Frekuensi Kemoterapi Responden

\begin{tabular}{|c|c|c|}
\hline Kriteria IMT & (n) & Persentase \\
\hline $\begin{array}{l}\text { Kekurangan Nutrisi Ringan } \\
\text { (IMT } 17,0-18,4 \mathrm{~kg} / \mathrm{m}^{2} \text { ) }\end{array}$ & 21 & $26,2 \%$ \\
\hline $\begin{array}{c}\text { Ideal } \\
\left(\text { IMT } 18,5-25,0 \mathrm{~kg} / \mathrm{m}^{2}\right)\end{array}$ & 59 & $73,8 \%$ \\
\hline JUMLAH & 80 & $100 \%$ \\
\hline $\begin{array}{l}\text { Tabel } 5 \text { menujukkan } \text { bahwa } \\
\text { sebagian besar responden memiliki } \\
\text { frekuensi kemoterapi dalam kategori }\end{array}$ & \multicolumn{2}{|c|}{$\begin{array}{l}\text { rendah (kemoterapi sebanyak 1-3 seri) } \\
(65 \%) \text {. }\end{array}$} \\
\hline
\end{tabular}

Tabel 6. Distribusi Status Nutrisi Responden

\begin{tabular}{|c|c|c|c|}
\hline Variabel & Mean \pm SD & Minimum-Maksimum & $\mathrm{Cl} 95 \%$ \\
\hline Status Nutrisi & $20,46 \pm 1,92$ & $17,7-23,7$ & $20,04-20,89$ \\
\hline
\end{tabular}

Tabel 7. Gambaran Umum Status Nutrisi

\begin{tabular}{ccc}
\hline Kategori & (n) & Persentase \\
\hline $\begin{array}{c}\text { Rendah (kemoterapi } \\
\text { sebanyak 1-3 seri) }\end{array}$ & 52 & $65 \%$ \\
\hline $\begin{array}{c}\text { Sedang (kemoterapi } \\
\text { sebanyak 4-5 seri) }\end{array}$ & 28 & $35 \%$ \\
\hline JUMLAH & 80 & $100 \%$ \\
\hline
\end{tabular}

Tabel 7 menunjukkan bahwa mayoritas responden memiliki status nutrisi dalam kategori ideal $(73,8 \%)$.

Tabel 8. Hubungan antara Frekuensi Kemoterapi dengan Status Nutrisi Responden

\begin{tabular}{cccc}
\hline \multicolumn{1}{c}{ Variabel } & p value & Koefisien Korelasi (r) & Koefisien Determinan (R) \\
\hline $\begin{array}{l}\text { Frekuensi Kemoterapi } \\
\text { dengan Status Nutrisi }\end{array}$ & 0,000 & $-0,790$ & $62,4 \%$ \\
\hline
\end{tabular}

Tabel 8 menunjukkan bahwa terdapat hubungan yang negatif dan kuat antara frekuensi kemoterapi dan status nutrisi responden.

\section{PEMBAHASAN}

Hasil penelitian menunjukkan bahwa sebagian besar responden memiliki frekuensi kemoterapi pada kategori rendah (kemoterapi sebanyak $1-3$ seri) (65\%). Astari (2015) juga mendapatkan hasil yang serupa yang menyatakan hampir sebagian besar pasien kanker serviks yang menjalani kemoterapi di RSUD Dr. Moewardi memiliki frekuensi kemoterapi dalam kategori rendah (48,5\%). Frekuensi kemoterapi dipengaruhi oleh empat faktor seperti stadium kanker, jenis obat sitotoksik yang digunakan, tujuan terapi serta respon tubuh (Unit Promosi Kesehatan RSUP Dr. Sardjito, 2015). Oleh karena peneliti menggunakan data berdasarkan rekam medis maka hanya mampu mengkaji dua faktor yaitu stadium kanker dan jenis obat sitotoksik yang digunakan.

Hasil penelitian menyatakan bahwa sebagian besar responden memiliki kanker stadium III $(53,8 \%)$. Suryapratama (2012) juga menyatakan bahwa sebagian besar pasien kanker yang menjalani kemoterapi di RSUD Dr. Kariadi Semarang berada pada 
stadium III (62\%). Hal tersebut dapat disebabkan oleh pada stadium dini (I dan II) gejala kanker belum terlihat secara jelas sehingga sebagian besar pasien mengetahui penyakitnya saat kondisi telah mengalami perburukan atau berada pada stadium lanjut (III) (Hardiano, 2015). Stadium kanker yang sudah bermetastasis biasanya membuat pasien menjalani seri kemoterapi yang lebih banyak (Melia dkk., 2013). Putri (2018) menyatakan bahwa pasien kanker yang berada pada stadium IV biasanya memiliki frekuensi kemoterapi lebih dari 4 seri.

Hasil penelitian juga menemukan jenis kombinasi BleomisinOncovin-Mitomisin terbanyak digunakan responden (43,8\%). Kombinasi obat ini biasanya paling efektif digunakan pada pasien kanker servik, namun obat ini juga dapat menurunkan massa tumor pada seluruh jenis kanker (Noviyani, 2017; Melia dkk., 2013). Frekuensi penggunaan obat harus disesuaikan dengan standar konsumsi dari obat tersebut (Pusat Informasi Obat Nasional, 2015). Penggunaan kombinasi obat Bleomisin, Oncovin dan Mitomisin biasanya memiliki standar konsumsi kurang atau sama dengan tiga kali dalam sebulan (Pusat Informasi Obat Nasional, 2015). Oleh karena itu, standar konsumsi obat yang lebih dari satu kali juga mengharuskan pasien memiliki frekuensi kemoterapi yang lebih dari satu seri.

Hasil penelitian menunjukkan mayoritas responden memiliki status nutrisi ideal (73,8\%). Astika (2017) juga menyatakan sebagian besar pasien kanker payudara di ruang perawatan kelas III RSUP Sanglah memiliki status nutrisi yang ideal. Faktor yang dapat mempengaruhi status nutrisi pasien kanker ialah usia, aktivitas fisik, infeksi, jenis kanker, efek samping terapi, tingkat pengetahuan, pendapatan, pekerjaan dan budaya (Departemen Kesehatan RI, 2011; Ang, Thomas, \& Young, 2012). Oleh karena peneliti menggunakan rekam medis maka data yang dapat terkaji hanya beberapa faktor saja.

$\begin{array}{ccc}\text { Hasil } & \text { penelitian menunjukkan } \\ \text { mayoritas } & \text { responden } & \text { merupakan }\end{array}$ kelompok dewasa madya (berusia 41-60 tahun) $(63,7 \%)$. Usia dewasa madya merupakan peralihan menuju penuaan yang rentan menimbulkan ketidakseimbangan hormon dan dapat memicu terjadinya kanker (Fadillah, 2017; Anggorowati, 2013). Hardiano (2015) juga menemukan sebagian besar pasien kanker yang menjalani kemoterapi di RSUD Arifin Achmad Pekanbaru berada pada usia 45-55 tahun. Usia lansia (> 60tahun) diketahui rentan mengalami gangguan nutrisi akibat dari proses degenerasi sel-sel yang menyebabkan fungsi tubuh dalam mencerna makanan menurun (Hariyanti, 2012).

Jenis kanker dan efek samping terapi juga menjadi faktor yang mempengaruhi status nutrisi (Ang, Thomas, \& Young, 2012). Hasil penelitian menunjukkan responden terbanyak menderita kanker nasofaring $(35 \%)$. Kanker nasofaring merupakan jenis kanker yang menyerang area di atas tenggorokan dan atau belakang hidung (Komite Penanggulangan Kanker Nasional, 2015). Jenis kanker dalam kaitannya dengan perubahan status nutrisi tergantung dari jenis organ yang diserang. Jenis kanker yang menyerang organ gastrointestinal merupakan jenis kanker yang dapat menyebabkan penurunan status nutrisi. Hal tersebut diketahui tidak hanya diakibatkan oleh terapi, namun juga patofisiologis penyakit yang memicu terhambatnya sistem cerna (Airley, 2009). 
Efek samping kemoterapi juga dapat menimbulkan dampak pada status nutrisi. Efek samping yang muncul dapat ditemukan melalui jenis obat sitotoksik yang digunakan. Hasil penelitian menunjukkan hampir sebagian besar responden menggunakan jenis obat sitotoksik berupa kombinasi Bleomisin-Oncovin-Mitomisin (43,8\%). Komite Penanggulangan Kanker Nasional (2015) menyatakan mayoritas pasien kanker yang mendapatkan terapi Bleomisin dan Mitomisin dapat mengalami supresi sumsum tulang, sedangkan Oncovin diketahui memiliki efek samping berupa neuropati pada kaki sebagai gejala yang paling umum terjadi. Efek samping kemoterapi yang secara langsung berdampak pada status nutrisi pasien kanker dapat berupa mual muntah, diare, anoreksia, mukositis dan depresi (Sutandyo, 2010).

$$
\text { Mual muntah merupakan }
$$

keluhan yang dapat dialami oleh semua pasien dengan kemoterapi (Ang, Thomas, \& Young, 2012). Penelitian Farrel, Brearley, Pilling, \& Molassiotis (2012) menemukan bahwa kondisi mual muntah dapat menimbulkan perubahan yang signifikan terhadap status nutrisi pasien kanker. Data dari penelitian tersebut juga menyatakan bahwa sebagian besar pasien kanker mengalami mual muntah dengan intensitas sedang - berat.

Diare dapat terjadi pada pasien yang mengonsumsi obat Flourouracil (Stein, 2010). Penggunaan Cisplatin juga diketahui dapat menyebabkan anoreksia sehingga pasien dapat mengalami penurunan berat badan (National Cancer Institute, 2009). Dua obat tersebut erat kaitannya dalam membuat status nutrisi pasien menurun.

Lalla, Bowe, Barasch, Elting, Epstein, \& Keefe (2014) menyatakan kemoterapi dapat menimbulkan mukositis yang mengganggu asupan nutrisi. Asupan nutrisi secara berkesinambungan mempengaruhi status nutrisi. Nurhidayah, Sholehati \& Nuraeni (2013) juga menyatakan bahwa pasien setelah kemoterapi dapat mengalami peningkatan skor kejadian mukositis.

Keluhan depresi setelah kemoterapi dapat mempengaruhi nafsu makan pasien (Thamaria, 2017). Caesandri \& Adiningsih (2015) menyatakan produksi hormon katekolamin dalam tubuh meningkat saat keadaan depresi. Hormon katekolamin merupakan hormon yang dapat menurunkan nafsu makan (anoreksia) (Thamaria, 2017).

Faktor di luar kondisi tubuh seperti pengetahuan dan pekerjaan juga mempengaruhi status nutrisi (Departemen Kesehatan RI, 2011). Hasil penelitian menunjukkan tingkat pendidikan terakhir responden hampir sebagian besar merupakan lulusan Sekolah Dasar (SD) (42,5\%). Tingkat pendidikan dapat mempengaruhi perilaku seseorang terutama dalam mempertahankan status gizi (Notoadmodjo, 2010). Hariyanti (2012) menyatakan sebagian besar pasien kanker payudara di RSUD Dr. Kariadi Semarang memiliki tingkat pendidikan terakhir berupa tidak sekolah, pengetahuan gizi yang kurang dan status gizi yang juga kurang.

Pekerjaan yang memiliki responden terbanyak dalam penelitian ini ialah buruh $(27,4 \%)$. Seseorang yang bekerja diketahui berpeluang untuk dapat memenuhi kebutuhan pangannya daripada yang tidak bekerja (Thamaria, 2017).

Hasil penelitian menunjukkan ada hubungan negatif kuat antara frekuensi kemoterapi dan status nutrisi responden ( $\mathrm{p}$ value $=0,000 ; \mathrm{r}=-0,790)$. Hal tersebut bermakna semakin banyak frekuensi kemoterapi maka semakin 
rendah status nutrisi yang dimiliki pasien kanker. Koefisien determinan pada hasil korelasi kedua variabel tersebut ditemukan sebesar $62,4 \%$ yang artinya sebagian besar faktor frekuensi kemoterapi dapat mempengaruhi status nutrisi pasien kanker.

Putri (2018) menjelaskan bahwa ada hubungan negatif antara frekuensi kemoterapi dengan status nutrisi pasien kanker. Pasien kanker payudara yang paling rentan memiliki status nutrisi kurang adalah pasien yang telah menjalani kemoterapi sebanyak 5-6 siklus.

Frekuensi kemoterapi berkaitan dengan keparahan keluhan efek samping. Halili, Tat, \& Letor (2017) menyatakan bahwa semakin banyak frekuensi kemoterapi yang dimiliki pasien maka semakin berat tingkat keparahan efek samping yang dirasakannya. Choi (2017) juga menyatakan keparahan efek samping yang dialami pasien mempengaruhi asupan makan serta status nutrisi tubuhnya. Oleh karena itu maka dapat dikatakan bahwa frekuensi kemoterapi memiliki hubungan yang bermakna terhadap status nutrisi pasien kanker melalui keparahan efek samping dan asupan nutrisi yang dimilikinya.

\section{KESIMPULAN DAN SARAN}

Frekuensi kemoterapi pada sebagian besar responden tergolong dalam katagori rendah dan status nutrisi mayoritas responden tergolong ideal. Terdapat hubungan yang bermakna negatif kuat antara frekuensi kemoterapi dan status nutrisi. Semakin banyak frekuensi kemoterapi menjadikan status nutrisi yang dimiliki pasien juga semakin rendah, begitu pula sebaliknya.

Penelitian ini memiliki beberapa keterbatasan sehingga peneliti menyarankan untuk peneliti selanjutnya agar menggunakan sumber data primer sehingga faktor-faktor yang belum terkaji dalam penelitian ini dapat diteliti lebih lanjut. Instansi kesehatan dan petugas kesehatan juga diharapkan memberikan pendidikan kesehatan mengenai kemoterapi dan hubungannya dengan status nutrisi serta melakukan pemantauan rutin terkait rencana kemoterapi pada pasien kanker.

\section{DAFTAR PUSTAKA}

Arley, R. (2009). Cancer Chemotherapy. UK : Wiley Blackwell Publication.

Ang, A., Thomas, J., \& Young, K. (2012). Nutritional risk of cancer patient who receping change of the ambulatory care setting: a prospective study. Singapore Nursing Journal. Diperoleh pada tanggal 6 November 2018 dari http:/eprint.quds.edu.au/81200/

Anggrowati, L. (2013). Faktor Resiko Kanker Payudara Wanita. Jurnal Keshatan Masyarakat 8 (2): 121 - 126.

Astri, K. (2015) Hubungan Frekuensi Kemoterapi dan Kecemasan Terhadap Asupan Energi, Protein, Lemak dan Karbohidrat Pada Pasien Kanker Serviks Di RSUD Dr. Moewardi. Diperoleh pada tanggal 1 Juni 2019 dari http://eprints.um..ac.id/37857/

Astka, N. (2017). Frkuensi Kemoterapi dapat Pengaruhi Asupan Zat Gizi dan Status Gizi pada Pasien Kanker Payudara di Ruang Perawatan Kelas III RSUP Sanglah Denpasar. Jurnal Skala Husada (14)1: 1 - 14.

Brnner \& Suddrth. (2013). Buku Ajar Keperwatan Medikal Bedah Edisi 8 Vol. 2. Jakarta: EGC.

Caesndri, S.O.P., \& Adiningsih, S. (2015). Peranan Dukungan Pendamping dan Kebiasaan Makan Pasien Kanker Selama Menjalani Terapi. Media Giizi Indonesia 10(2): 157 - 165

Choi, K. (2017). The Relationships among Chemotherapy-Induced Nausea and Vomiting (CINV), NonPharmacological Coping Methods, and Nutritional Status in Patients with Gynecologic Cancer. Journal of Korean Academy Nursing 47(6): 731 743.

Citra, W. (2012). Gambaran Efek Samping Kemoterapi Berbsis Antrasiklin pada Pasien Kanker Payudara di RSUD Dr. 
Soedarso Pontianak. Diperoleh pada tanggal 5 November 2018 dari jurnal.untn.ac.id/index.php/jfk/article/v iew/1769

Departemen Kesehatan RI. (2011). Pedoman Praktis Memantau Status Gzi Orang Dwasa. Diperoleh pada tanggal 24 Desember 2018 dari gizi.dpkes.go.id/

Fadillah, D. (2017). Insidensi Penyakit Kanker di RSUP Dr. Wahidin Sudirohusodo Makassar Periode Januari 2015 - Juni 2017. Diperoleh pada tanggal 18 Desember 2018 dari digilib.unhas..ac.id

Farrell, C., Brearley, S. G., Pilling, M., \& Molassiotis, A. (2012). The impact of chemotherapy-related nausea on patients' nutritional status, psychological distress and quality of life. Spportive Care in Cancer 21(1): 59-66.

Fu, K. \& Pan, H. (2017). Nutritional Status and Risk Factors for Malnutrition in CRC Patients Undergoing Neoadjuvant Therapy. Biomdical Research 28 (10): 4406-4412.

Halili, Y., Tat, F., \& Letor., M.K. (2017). Hubungan Karakteristik dan Frekuensi Kemoterapi dengan Tingkat Gangguan Fisik (Alopesia, Nausea dan Vomit) pada Pasien Kanker yang Menjalani Kemoterapi di Ruangan Mutis RSUD Prof. Dr. W. Z. Johannes Kupang. CHMK Nrsing Scientific Journal 1(2): $31-40$

Hardiano., R. (2015). Gambaran Indeks Massa Tubuh pada Pasien Kanker yang Menjlani Kemoterapi. JOM 2(2); 1381 1388.

Hariani, R.. (2009). Kecukupan Nutrisi pada Pasien Kanker. Indonesian Journal of Cancer 4: 140 - 143.

Hariyanti, S. (2012). Faktor-Faktor yang Berhubungan dengan Status Gizi Penderita Kanker Payudara. Diperoleh pada tanggal 23 Juni 2019 dari lib.unns.ac.id/698/

Hidayattulah, M.T. (2015). Profil Adverse Drug Reactions Cisplatin Regimen Kemoterapi pada Pasien Kanker Servik di RSUD Prof. Dr. Margono Soekardjo Purwokerto. Diperoleh pada tanggal 5 November 2018 dari http://repsitory.ump.ac.id/708/

Khairina, D. (2009). Faktor-faktor yang Berhubungan dengan Status Gizi Berdasarkan IMT pada Pembantu Rumah Tangga (PRT) Wanita di
Perumahan Duta Indah Bekasi Tahun 2009. Diperoleh pada tanggal 23 Desember 2018 dari http://lib.uii.ac.id/file?file=digital/1225 $\underline{25 /}$

Komite Penanggulangan Kanker Nasional. (2015). Pedoman Kanker di Indonesia. Jakarta: Kemenkes.

Lalla, R.V., Bowen, J., Barasch, A., Elting, L., Epstein, J., Keefe, D.M. (2014). MASCC/ISOO clinical practice guidelines for the management of mucositis secondary to cancer therapy. Cncer 120(10): 1453-1461.

Melia, E.K.A., Putrayasa, I.D.P.Gd., Azis, A.

(2013). Hubungan Frekuensi

Kemoterapi terhadap Status

Fungsional Pasien Kanker yang Menjalani Kemoterapi di RSUP Sanglah Denpasar. Diperoleh pada tanggal 5 November 2018 dari download..prtalgaruda.org/article.php? article $=80896 \& \mathrm{val}=956$

National Cancer Institute. (2009). Diarrhea and Cancer Treatment. Diperoleh pada tanggal 20 Januari 2019 dari www.cancer..gov/cancer..info/

Notoadmodjo, S. (2010). Promosi Kesehatan dan Ilmu Perilaku. Jakarta: Rineka Cipta.

Noviyni, R. (2017). Efek Kemoterapi Bleomisin, Vincristin, Mitomisin dan Karboplatin terhadap Massa Tumor dan Infiltrasi Parametrium pada Pasien Kanker Serviks: Studi Kasus di RSUP Sanglah Denpasar. Jurnal Farmasi Klinik Indonesia 6(3); 164-170.

Nrhidayah, I., Sholehati, T., Nuraeni, A. (2013). Skor Mukositis pada Anak dengan Kanker yang Sedang Menjalani Kemoterapi di RSUP Dr. Hasan Sadikin Bandung. Jurnal Keperawatan Sudirman 8(1): 1 - 13

Priestman, T. (2012). Cancer Chemotherapy in Clinical Practice Second Edition. UK: Springer.

Pusat Informasi Obat Nasional. (2015). Farmakologika Keganasan dan Imunosupresif. Diperoleh pada tanggal 11 Januari 2019 dari http://pionas.pom..go.id

Putri, N. (2018). Hubungan Siklus Kemoterapi dengan Status Gizi Pasien Kanker Payudara di Ruang Rawat Inap Rumah Sakit Umum Daerah Dr. Zainoel Abidin Banda Aceh. Diperoleh pada tanggal 14 Februari 2019 dari etd.unyiah.ac.id/36937 
Rif’atunnia, S.. (2017). Faktor Risiko terjadinya Mual Muntah Lambat akibat Kemoterapi pada Pasien Kanker Payudara. Jurnal Ilmiah Kesehatan Diagnosis 11(4): 388 - 392.

Riset Kesehatan Dasar. (2017). Prevalensi Kanker di Indonesia Tahun 2017. Jakarta: Kementerian Kesehatan RI.

Riset Kesehatan Dasar. (2018). Situasi Penyakit Kanker di Indonesia Tahun 2018. Jakarta: Kementerian Kesehatan RI.

Stein, A. (2010). Chemotherapy-induced diarrhea: pathophysiology, frequency and guideline-based management. Therapeutic Advances in Medical Oncology Journal 2(1): 51-63.

Suryapratama, S. A. (2012). Karakteristik Penderita Kanker Serviks di RSUD Dr. kariadi Semarang. Diperoleh pada tanggal 30 Mei 2019 dari http://eprints.uss.ac.id./14701/

Susanti, D. (2016). Pengaruh Terapi Relaksasi Autogenik terhadap Mual Muntah Post Kemoterapi pada Pasien Kanker Payudara di Rumah Sakit Islam Sultan Agung Semarang. Diperoleh pada tanggal 5 November 2018 dari http://repository.unssula.ac.id/10538/

Sutandyo, N. (2010). Nutrisi pada Pasien Kanker yang Mendapat Kemoterapi. Indonesian Journal of Cancer 4: 144 148.

Thamaria, N. (2017). Penilaian Status Gizi. Jakarta: Kementerian Kesehatan Republik Indonesia.

Unit Promosi Kesehatan RSUP Dr. Sardjito. (2015). Kemoterapi. Diperoleh pada tanggal 20 Desember 2018 dari www. sardjito.co.id

World Health Organization. (2018). National Cancer Control Programmes. Diperoleh pada tanggal 5 November 2018

dari http://www.who.int/cancer/en/ 